\title{
Investigation of Behaviors of the Epilepsy Patients' Relatives During Seizure and its Association with Their Knowledge Regarding Epilepsy
}

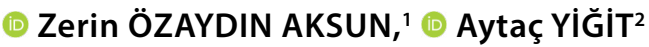

'Department of Neurology, Ankara University Faculty of Medicine, Ankara, Turkey

2Department of Neurology, Hisar Hospital, İstanbul, Turkey

\begin{abstract}
Objectives: Relatives of epilepsy patients tend to intervene their patients during epileptic seizure with an intention to help them. Usually not based on a medical knowledge, these behaviors may harm the patient rather than providing benefit. This study aimed to investigate interventional behaviors to the seizure to build a base for informing epilepsy patients and their relatives.

Methods: In this study, a questionnaire prepared by us was applied to the participants who met the inclusion criteria.

Results: A total of 23 subjects, consisting of 20 females and three males, participated to the survey. Mean age of the participants was 42 . There were four patients who thought the event to be epilepsy. The percentage of participants who declared that they observed a seizure before was $47.8 \%$. When the interventions were grouped, it found that $52.2 \%$ of participants intervened to the surrounding, while $47.8 \%$ intervened to the patient. About half of the participants said "epilepsy is a brain disorder." No participants associated epilepsy with magic or supernatural power. Conclusion: As our study based on questionnaire about witnessing a seizure, we sought answers to the question of "what you did during the seizure." Approximately half of the relatives of the patients (47.8\%) chose to intervene in their patients; the conclusion that it is important to inform the society becomes meaningful when considering that the interventions may have the potential risk to their patients.
\end{abstract}

Keywords: Epilepsy; intervention of seizure; seizure.

Cite this article as: Özaydın Aksun Z, Yiğit A. Investigation of Behaviors of the Epilepsy Patients' Relatives During Seizure and its Association with Their Knowledge Regarding Epilepsy. Epilepsi 2021;27:96-101.

\section{Introduction}

Epileptic seizure is originated from increased, rapid, and focal electrical discharges of neuron clusters in the cerebral cortex. A short-term and transient alteration with sudden onset is seen in consciousness, and behavioral, emotional, motor and/or perceptive functions during the seizure. ${ }^{[1]}$

As one of the most common chronic neurologic conditions in both developed and developing countries, epilepsy has negative impacts on morbidity, mortality, and work productivity. ${ }^{[2]}$

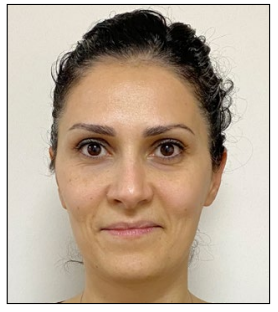

Zerin ÖZAYDIN AKSUN, M.D.
Corresponding author

Zerin ÖZAYDIN AKSUN, M.D.

e-mail zoaksun@ankara.edu.tr

Received 08.09.2020

Accepted 09.11.2020

Online date 02.04.2021

Content of this journal is licensed under a Creative Commons Attribution-NonCommercial 4.0 International License.

(c) 2021 Turkish Epilepsy Society
It is estimated that the prevalence of epilepsy is 6 and $18.5 / 1000$ people in developed and developing countries, respectively; as determined by epidemiological studies performed with the protocol of the World Health Organization. Eight studies published in Turkey between 1995 and 2010 reported prevalence of the epilepsy as $7.35 / 1000 .^{[3-10]}$

The diagnosis of epilepsy is mainly established by clinical manifestations, based on the detailed description of the seizures by the patient and its witnesses.

In this context, we aimed to understand what kind of interventions is made in a disease whose diagnosis and intervention are based on witnessing, and the state of knowledge and awareness in the society.

\section{Materials and Methods}

This is a survey-based study to assess behaviors of witnesses of generalized tonic-clonic seizures during the seizure and to show the association of these behaviors to their knowledge regarding epilepsy. The survey consisting of a questionnaire was prepared by us and applied in a face-to- 


\section{Epilepsi Hastalarının Yakınlarının Nöbet Sırasındaki Davranışları ve Bunun Epilepsi Hakkındaki Bilgileri ile İlişkisi}

\section{$\ddot{0 z}$}

Amaç: Epilepsi hastalarının yakınları, epileptik nöbet sırasında hastalarına yardım etme niyetiyle müdahale etme eğilimindedir. Genellikle tıbbi bir bilgiye dayanmayan bu davranışlar, fayda sağlamaktan çok hastaya zarar verebilir. Bu çalışma, epilepsi hastalarını ve yakınlarını bilgilendirmek için bir temel oluşturmak için nöbete müdahale davranışlarını araştırmayı amaçlamıştır.

Gereç ve Yöntem: Bu çalışmada, dahil olma kriterlerini karşılayan hasta yakınlarına tarafımızca düzenlenen bir anket uygulanmıştır.

Bulgular: Katılımcıların 20'si kadın, 3'ü erkek olup ortalama yaş 42 idi. Olayın sara/epilepsi olduğunu düşünen 4 kişi vardı. Katılımcıların \%47.8'i daha önce bir nöbet görmüş olduklarını belirtti. Yapılan işlemler hastaya veya çevreye müdahale olarak ayrıldığında, \%52.2'si çevreye, \%47.8'i hastaya müdahale etmeyi seçti. Katılımcıların yaklaşık yarısı "epilepsi bir beyin hastalığıdır" dedi ve hiçbiri epilepsiyi büyü veya doğaüstü bir güç ile ilişkilendirmedi.

Sonuç: Bizim çalışmamız nöbet tanıklığına ilişkin sorulara dayandığından "nöbet sırasında ne yaptınız" sorusuna yanıtlar arandı. Hasta yakınlarının yaklaşık yarısının (\%47.8) hastasına müdahale etmeyi seçtiğini düşünürsek, yapılan müdahalelerin zarar verme potansiyeli olabileceği göz önüne alındığında toplumun bilgilendirilmesinin ne kadar önemli olduğu sonucu anlam kazanmaktadır.

Anahtar sözcükler: Epilepsi; nöbet; nöbete müdahale.

face fashion to the patients and their relatives who met the inclusion criteria, presenting to our outpatient clinic. Inclusion criteria for the study were having a history of clinical epileptic seizure for the patient and intervening to a seizure for the first time for the witness. The study was performed on voluntary basis after obtaining written consent from the participants. Ethics committee approval was obtained.

\section{The questionnaire}

- What did you think of this event?

- Have you ever seen any seizure of your patient before?

- Have you ever seen any seizure of any one before?

- What did you feel while your patient was having a seizure?

- What did you do while your patient was having a seizure?

- What was your aim in doing what you did during the seizure?

- Did your patient benefit from what you did during the seizure?

- What was your source of information about what you did during the seizure?

- What do you know about the epilepsy disease?

\section{Results}

Among those applied to the neurology clinic 23 participants who met inclusion criteria enrolled to the study. Mean age of the participants was 42 (range: 19-56 years), consisting of 20 females and three males.

Four of the witnesses declared that they though the event to be epilepsy. The answers to this question are summarized in Table 1. The percentage of participants who had ever seen a seizure was $47.8 \%$. All the witnesses stated that they felt fear during the event. The interventions taken during the seizure was declared as following: "I spilt water," "I made her/him smell onion or garlic," "I put something to her/his mouth," "I poured cologne on her/his face," "I tried to make her/him drink sugared water," "I tried to give mouthto-mouth resuscitation," "I gave painful stimulus," "I tried to make her/his body flat," "I moved surrounding items away," or "I opened the windows." The latter two were regarded as intervention to the surrounding area, and others were regarded as intervention to the patient. Near half of the participants $(52.2 \%)$ were detected to prefer intervention to the surrounding, and the remaining $47.8 \%$ was found to prefer intervening to the patient. Some of the participants stated that they made several different interventions. The interventions made are summarized in Table 2.

The aim of the things done during the event was declared as "to make the patient recover consciousness" by some participants and as "to protect from possible injuries" by some others. Near one-third of the participants (30.4\%) stated

Table1. What did you think of this event?

\begin{tabular}{lcc}
\hline $\begin{array}{l}\text { What did you } \\
\text { think of this event? }\end{array}$ & Frequency & Percentage \\
\hline Nothing & 5 & 21.7 \\
Epilepsy & 4 & 17.4 \\
Nothing & 4 & 17.4 \\
Stroke & 3 & 13 \\
Heart attack & 3 & 13 \\
Fall & 2 & 8.7 \\
Psychogen & 2 & 8.7 \\
Total & 23 & \\
\hline
\end{tabular}


Table 2. What did you do while your patient was having a seizure?

\begin{tabular}{lcc}
\hline What did you do while your patient was having a seizure? & Frequency & Intervention \\
\hline I spilt water & 9 & Intervening to the patient \\
I made her/him smell onion or garlic & 1 & 1 \\
I put something to her/his mouth & 3 \\
I poured cologne on her/his face & 1 \\
I tried to make her/him drink sugared water & 1 \\
I tried to give mouth-to-mouth resuscitation & 1 \\
I gave painful stimulus & 1 & Intervening to surrounding area \\
I tried to make her/his body flat & 6 & 5 \\
I moved surrounding items away & 5 \\
I opened the windows &
\end{tabular}

that their patients benefited from their actions performed during the seizure. While $47.8 \%$ of patients responded to the question about "what is epilepsy disease" as a brain disease, the remaining (52.2\%) participants did not have any idea.

\section{Discussion}

There have been numerous studies evaluating viewpoints and stigmas regarding epilepsy. With the aim of gaining insights about the public opinion about epilepsy, these studies consisted of questioning various populations about the knowledge of epilepsy, things that would be done during a seizure, and attitudes and behaviors toward epileptic patients. In this study, we collected participants' responses about the things they did during the seizure, the aim and the source of information of these actions and compared them with the findings of the similar studies.

Familiarity with epilepsy- A study performed with 587 students in Health Sciences of Manipal University and evaluating attitudes regarding epilepsy reported that $92.5 \%$ of students were aware of epilepsy and $41.6 \%$ declared to see an epileptic seizure. ${ }^{[11]}$ In another study performed in USA with Chinese and Vietnamese adults, $58 \%$ of participants stated that they either witnessed or saw seizure on TV. ${ }^{[12]}$ In the study performed in Batibo region of Cameroon, 87.7\% of 350 participants declared that they witnessed a seizure. Since Batibo is a small area with a high prevalence of epilepsy, study authors attributed this high rate to the fact that many of these people may recognize or see the same epileptic patients. ${ }^{[13]}$ A study in Ebolowa and Sangmelima regions of Cameroon reported that $75 \%$ of 456 participants ever saw a seizure. ${ }^{[14]}$ The study performed with basic and clinical medicine students in Nigeria reported that $46.8 \%$ of students were familiar with someone with epilepsy. ${ }^{[15]} \mathrm{A}$ 2007 study in Isparta reported 53\% of 582 participants to ever see a seizure. ${ }^{[16]}$ Another study performed in Malesia in 2010 reported that $62.9 \%$ of 615 participants witnessed a seizure. ${ }^{[17]}$ In the study by Aydemir, $30.7 \%$ of participants never heard of epilepsy and $68.4 \%$ either were not familiar with an epileptic person or did not read something about epilepsy. ${ }^{[18]}$ In our study, the percentage of participants who ever saw epileptic seizure was $47.8 \%$. There were four people who thought that the event they witnessed was epilepsy; the reason for this opinion was that they previously saw someone suffering a seizure.

Intervening in the seizure- In the study in Manipal, 51\% of participants declared that they would move the objects that the sufferer may hit away, $65.4 \%$ to move the victim to a safer place, and $20 \%$ to put a hard object into the mouth of the patient. In fact, the latter originates from the belief that sharp objects would repel demonic souls and resolve the seizure. ${ }^{[11]}$

The US study reported that $75 \%$ of participants found it appropriate to put a hard object into the mouth of a person suffering a seizure. ${ }^{[12]}$ In a study performed in Yuksekova and consisting of 130 epileptic patients, 130 patient's relatives, and 130 control subjects, 76 relatives stated that they would call ambulance if their patient had experienced a seizure, and 83 relatives declared that they would move the victim to a safer place. The number of participants declaring that they would spill water on the patient's face was similar in control and relative groups (28 and 22 participants, respectively). ${ }^{[19]}$

In a study performed in Kutahya and Yuksekova, while the percentage of participants who would make her/his seizing patient to smell something was $32.4 \%$ and $8.5 \%$, respectively; those declaring that they would spill water on the sufferer's face was $19.4 \%$ and $21.5 \%$, respectively. ${ }^{[20]}$ The study by Atakli et al. ${ }^{[21]}$ reported that the percentages of advocates of 
making the patient smell onion and putting a spoon on the sufferer's mouth was $17 \%$ and $9.1 \%$, respectively.

Almost half of the epileptic patients claimed that putting an object to the mouth was wrong, as reported by a Korean study in $2006 .{ }^{[22]}$ In the study by Long et al., ${ }^{[23]} 41 \%$ of epileptic patients advocated the idea of putting an object to the mouth. The study by Aydemir reported that the percentages of people who thought it was wrong to make the epileptic patient smelling onion and to spill water on the face were $59.3 \%$ and $36.5 \%$, respectively. ${ }^{[18]}$

Since our study was based on the questions regarding witnessing of the seizure, we looked for what the witnesses did during the seizure. The percentage of patients who stated that they spilt water onto the sufferer's face was 39.1. While most of participants told that they did it to recover the patient's consciousness, one participant stated to previously see the behavior of spilling water on the face and to associate this behavior with a feeling of patient's relief. No relative declared to move the patient into another place. A participant (4.3\%) stated that $s /$ he tried to put an object into the sufferer's mouth, where the aim was to prevent the patient from biting his/her own tongue, though s/he had no source for this knowledge.

Causes of epilepsy-Many studies reported that there were misbeliefs about the association of epileptic seizures with mystic events or supernatural powers. In fact, people tend to use several methods such as consulting hodja, wearing amulets, or attending some religious ceremonies. ${ }^{[24-26]}$

The study in Manipal reported that $41 \%$ of participants associated epilepsy with brain tumor, and $12.4 \%$ had no idea. ${ }^{[11]}$ The US study showed that $42 \%$ of participants regarded the epilepsy as a mental disease. ${ }^{[12]}$ The percentage of participants who selected the reason for epilepsy as the brain disease was $27 \%$ in study performed in Batibo. Around onethird of the patients (34.4\%) associated the disease with magic, which, in fact, was the most common belief for the cause of epilepsy. ${ }^{[13]}$ The study in Ebolowa and Sangmelima of Cameroon reported that $43 \%$ of participants associated the disease with a brain disorder. The percentage of participants who indicated magic as the causing factor was 13.7. The misbelief of magic was more prevalent in studies performed in Batibo and Ghana, which was attributed to the differences in cultural beliefs. ${ }^{[14]}$

The study performed in Isparta showed the percentage of answers of reason for epilepsy as brain disease and mental disease as $42 \%$ and $16 \%$, respectively. ${ }^{[16]}$
While most of the patient's relatives in the study performed in Yuksekova in 2010 declared that the reason for epilepsy was brain disorder, the percentage of those having no idea was similar between epileptic patients, patient's relatives, and control group. ${ }^{[19]}$

The study in Yuksekova and Kutahya reported that the percentage of statement of the cause of epilepsy as brain disorder was 78.5 and 52.2, respectively. In Yuksekova, all participants declared that they would also try alternative methods apart from medical therapy. ${ }^{[20]}$ The need for seeking alternative advices suggests high prevalence of the misbelief of the causality to the religious factors regarding epilepsy.

In our study, the answer of brain disorder as the causing factor was $47.8 \%$. As we did not question education level of our patient, we could not determine its association to this finding. Although our result was similar to the study in Isparta, the answer of mental disease was $16 \%$ in that study, which was null in our study. ${ }^{[16]}$

In Laos, where the epilepsy is known as "mad pig disease," $25-42 \%$ of the population thought that the disease originated from supernatural powers, and $10-21 \%$ thought that it was transmitted through the habit of eating pork meat. ${ }^{[27]}$

In fact, no participant in our study declared the belief of reasoning the disease to originate from mental disease or magic. This may be due to face-to-face setting of the survey. Indeed, collecting written data would be more likely to reflect actual opinions.

Conclusion- The percentage of witnessing a seizure before was $47.8 \%$ in our study, which was similar to that in studies in Manipal and Nigeria. This was 53\% in the study performed in Isparta. High percentages of witnessing above 75\% reported by the studies in Cameroon, Batibo, and Sangmelima were explained by the fact that these regions were small and had high prevalence of epilepsy.

The percentage of those having the knowledge that epilepsy is a brain disease was $41 \%, 27 \%, 43 \%, 42 \%, 78.5 \%$, and $52.2 \%$ in Manipal, Batibo, Cameroon, Isparta, Yuksekova, and Kutahya, respectively; which could be regarded as similar to that of our study.

Most important aspect of our study was that it included questions regarding interventions and their aims during witnessing the seizures. While more than $25 \%$ of medical students in Nigerian study declared that they would put 
an object into the sufferer's mouth, ${ }^{[15]}$ this was $9.2 \%$ in the study by Atakli et al. ${ }^{[21]}$ and $4.3 \%$ in our study.

Spilling water onto the patient's face during the seizure was declared by 19.4 and $21.5 \%$ of participants in Kutahya and Yuksekova, respectively. ${ }^{[20]}$ On the other hand, those thinking that spilling water would be wrong constituted $36.5 \%$. [18] Spilling water on the patient's face during the seizure was declared by $39.1 \%$ of our participants, which was determined as higher compared to other studies. One participant (4.3\%) stated that $s / h e$ would make the patient smell onion. Making the patient smelling something was declared by $32.4 \%$ and $8.5 \%$ of participants in Kutahya and Yuksekova, respectively. ${ }^{[20]}$ The participants having the opinion that making the patient smelling onion during the seizure is wrong constituted $59.3 \%$ in the study by Aydemir. ${ }^{[18]}$

None of our participants associated epilepsy with magic or supernatural powers, which was considered as pleasing and promising in terms of the tendency of the public toward more educational activities.

Study Limitations- The low number of participants is the limitation of our study. The approach during epileptic seizures in our society may be demonstrated more clearly with studies more participants.

Improper intervention to a seizure can be harmful. Raising awareness on this issue is another responsibility of healthcare professionals.

Informed Consent- Written informed consent was obtained from the patients for the publication of the this study and the accompanying images.

Ethics Committee Approval- This study was approved by the Ankara University Faculty of Medicine Clinical Research Ethics Committee (Approval No: 25.05.2009/152-4770).

Peer-review- Externally peer-reviewed.

Authorship Contributions- Concept: A.Y.; Design: A.Y.; Supervision: A.Y.; Data collection \&/or processing: Z.Ö.A.; Analysis and/or interpretation: A.Y., Z.Ö.A.; Literature search: Z.Ö.A.; Writing: Z.Ö.A.; Critical review: A.Y., Z.Ö.A.

Conflict of interest-The authors declare that they have no conflict of interest.

Financial Disclosure: The authors declared that this study has received no financial support.

\section{References}

1. Bora İ, Yeni N, Gürses C. Mekanizmalar ŞTET. Epilepsy 1(1):2936.
2. Yılmaz H, Mavioğlu H, Tosun $C$, Okudur İ. Demographic and clinical features of our epilepsy cases: an outpatient clinic based study. Dusunen Adam The Journal of Psychiatry and Neurological Sciences 2000;13(3):180-4.

3. Karaaĝaç $N$, Yeni $S$, Şenocak $M$, Bozluolgay $M$, Savrun FK, Özdemir $\mathrm{H}$, et al. Prevalence of epilepsy in Silivri, a rural area of Turkey. Epilepsia 1999;40(5):637-42. [CrossRef]

4. Çalışır N, Bora I, Irgil E, Boz M. Prevalence of epilepsy in Bursa city center, an urban area of Turkey. Epilepsia 2006;47(10):1691-9. [CrossRef]

5. Aziz H, Güvener A, Akhtar S, Hasan K. Comparative epidemiology of epilepsy in Pakistan and Turkey: Population-based studies using identical protocols. Epilepsia 1997;38(6):716-22. [CrossRef]

6. Akyüz A, Bekar D, Sümer H, Topalkara K, Topaktaş S, Dener Ş. Sivas II Merkezinde Tabakalı Örneklem Yöntemi Ille Gerçekleştirilen Epilepsi Prevalans Çalışması; 1999.

7. Onal AE, Tumerdem Y, Ozturk MK, Gurses C, Baykan B, Gokyigit $A$, et al. Epilepsy prevalence in a rural area in Istanbul. Seizure 2002;11(6):397-401. [CrossRef]

8. Aydin A, Ergor A, Ergor G, Dirik E. The prevalence of epilepsy amongst school children in Izmir, Turkey. Seizure 2002;11(6):392-6. [CrossRef]

9. Serdaroglu A, Ozkan S, Aydin K, Gücüyener K, Tezcan S, Aycan $S$. Prevalence of epilepsy in Turkish children between the ages of 0 and 16 years. J Child Neurol 2004;19(4):271-4. [CrossRef]

10. Velioglu SK, Bakirdemir M, Can G, Topbas M. Prevalence of epilepsy in Northeast Turkey. Epileptic Disord 2010;12(1):22-37.

11. Panda SB, Prabhu K, Rao S, Rao A, Rao G, Datta A, et al. Evaluation of knowledge of and attitudes toward epilepsy among the health science students of Manipal University. Epilepsy Behav 2011;20(3):447-9. [CrossRef]

12. Chung K, Ivey SL, Guo W, Chung K, Nguyen C, Nguyen C, et al. Knowledge, attitudes, and practice toward epilepsy (KAPE): A survey of Chinese and Vietnamese adults in the United States. Epilepsy Behav 2010;17(2):221-7. [CrossRef]

13. Njamnshi AK, Angwafor SA, Tabah EN, Jallon P, Muna WF. General public knowledge, attitudes, and practices with respect to epilepsy in the Batibo Health district, Cameroon. Epilepsy Behav 2009;14(1):83-8. [CrossRef]

14. Njamnshi AK, Yepnjio FN, Tabah EN, Dema F, Angwafor SA, Fonsah JY, et al. Public awareness, perceptions, and attitudes with respect to epilepsy in Ebolowa and Sangmelima-Urban Cameroon. Epilepsy Behav 2009;14(4):628-33. [CrossRef]

15. Ekeh BC, Ekrikpo UE. The knowledge, attitude, and perception towards epilepsy amongst medical students in Uyo, Southern Nigeria. Adv Med 2015;2015:876135. [CrossRef]

16. Demirci S, Dönmez CM, Gündoğar D, Baydar ÇL. Public awareness of, attitudes toward, and understanding of epilepsy in Isparta, Turkey. Epilepsy Behav 2007;11(3):427-33. [CrossRef]

17. Neni SW, Latif AZ, Wong SY, Lua PL. Awareness, knowledge and attitudes towards epilepsy among rural populations in East Coast Peninsular Malaysia: A preliminary exploration. Seizure 2010;19(5):280-90. [CrossRef] 
18. Aydemir N. Developing two different measures for assessing knowledge of and attitudes toward epilepsy for the Turkish population. Epilepsy Behav 2008;12(1):84-9. [CrossRef]

19. Degirmenci Y, Karaman HI, Bakar C. Perceptions of epilepsy of three different groups in Turkey. Epilepsy Behav 2010;19(3):315-22. [CrossRef]

20. Degirmenci Y, Kabay SC, Yilmaz Z, Bakar C, Karaman HI. Perception of epilepsy in Turkey in the light of two different cities. Acta Clin Croat 2013;52(1):59-66.

21. Atakli D, Ak PD, Guveli BT, Yuksel B. Knowledge of epilepsy among persons with epilepsy in Turkey. Epilepsy Behav 2016;57(A):41-5. [CrossRef]

22. Choi-Kwon S, Kim E, Youn S, Choi J, Lee SK, Chung CK. Common misconceptions in people with epilepsy. J Clin Neurol 2006;2(3):186-93. [CrossRef]
23. Long L, Reeves AL, Moore JL, Roach J, Pickering CT. An assessment of epilepsy patients' knowledge of their disorder. Epilepsia 2000;41(6):727-31. [CrossRef]

24. Ab Rahman AF. Awareness and knowledge of epilepsy among students in a Malaysian University. Seizure 2005;14(8):593-6.

25. Jacoby A, Snape D, Baker GA. Epilepsy and social identity: The stigma of a chronic neurological disorder. Lancet Neurol 2005;4(3):171-8. [CrossRef]

26. Scambler G, Hopkins A. Generating a model of epileptic stigma: The role of qualitative analysis. Soc Sci Med 1990;30(11):118794. [CrossRef]

27. Tran DS, Odermatt $P$, Singphuoangphet $S$, Druet-Cabanac M, Preux PM, Strobel M, et al. Epilepsy in Laos: Knowledge, attitudes, and practices in the community. Epilepsy Behav 2007;10(4):565-70. [CrossRef] 